\title{
In reply: Encouraging a bare minimum while striving for the gold standard: a response to the updated WHO-WFSA guidelines
}

\author{
Adrian W. Gelb, MBChB, FRCPC • Wayne W. Morriss, MBChB • Walter Johnson, MD • \\ Alan F. Merry, MBChB, FANZCA, FFPMANZCA on behalf of the International \\ Standards for a Safe Practice of Anesthesia Workgroup
}

Received: 18 July 2018/Accepted: 28 July 2018/Published online: 29 August 2018

(C) Canadian Anesthesiologists' Society 2018

\section{To the Editor,}

We are thankful for the opportunity to respond to the letter from Dr. Hendel et al. ${ }^{1}$ addressing the World Health Organization-World Federation of Societies of Anaesthesiologists (WHO-WFSA) International Standards for a Safe Practice of Anesthesia ${ }^{2,3}$ reiterating their previously stated concern that such standards set the bar too high. ${ }^{4}$

The WHO-WFSA workgroup was globally representative and was balanced for sex, geography, and high-, middle-, and low-income country membership. Thus, the advice of representatives from low-income countries in different parts of the world was sought and included. This is in contrast to the authorship group of

This reply is jointly published in the Canadian Journal of Anesthesia and Anesthesia \& Analgesia.

\footnotetext{
A. W. Gelb, MBChB, FRCPC ( $\square)$

Department of Anesthesia \& Perioperative Care, University of California, San Francisco, San Francisco, CA, USA

e-mail: adrian.gelb@ucsf.edu
}

W. W. Morriss, MBChB

University of Otago, Christchurch Hospital, Christchurch, New Zealand

W. Johnson, MD

Services Organization and Clinical Interventions Unit (SCI), Service Delivery and Safety Department (SDS), Health Systems and Innovation (HIS), World Health Organization, Geneva, Switzerland

\section{A. F. Merry, MBChB, FANZCA, FFPMANZCA \\ Department of Anaesthesiology, University of Auckland, Auckland, New Zealand}

A. F. Merry, MBChB, FANZCA, FFPMANZCA Department of Anaesthesia, Auckland City Hospital, Auckland, New Zealand
Hendel et al. where only a part of Africa was represented among low-income countries.

Hendel et al. seem to have missed the distinction made in our Standards document between emergency surgery to save life or limb and purely elective or semi-elective surgery. Their disconcerting statement "We do a disservice to those who rely on a bare minimum by implying that they should have oxygen, safety monitors, and essential medicines at all times" ${ }^{1}$ is difficult to reconcile with the setting of standards. Their statement serves to sanction all surgery independent of urgency in the absence of basic requirements. The WHO-WFSA workgroup strongly disagrees with such a sanction. The Standards document accommodates the need for anesthesia in the absence of these minimum standards in exceptional circumstances with an explicit statement that "In some resource-poor settings, even HIGHLY RECOMMENDED (i.e., minimum expected standards) may not currently be met. In these settings, the provision of anesthesia should be restricted to procedures that are absolutely essential for the immediate (emergency) saving of life or limb. If HIGHLY RECOMMENDED standards are not met, provision of anesthesia for elective surgical procedures is unsafe and unacceptable." 3

Standards are by definition "A required or agreed level of quality or attainment; something used as a measure, norm, or model in comparative evaluations". 5 They are not intended to "imply" what that level is-they state it explicitly. How they are implemented depends on decisions made locally at a hospital, regional, or national level. We have previously pointed out that the failure of local political processes does not represent the failure of appropriate standards. ${ }^{6}$ Standards are a tool to be used in the political process of establishing best practices in the interests of patient safety and wellbeing.

We wish to assure Hendel et al. that the WFSA is playing a very active role, together with national societies, in ensuring that anesthesia is an integral part of national 
surgery-obstetric-anesthesia planning. The WHO-WFSA International Standards for a Safe Practice of Anesthesia are proving to be an invaluable resource during those planning processes. We are concerned that the explicit bare minimum step-wise approach previously promulgated by these authors, ${ }^{4}$ and now reiterated once again, ${ }^{1}$ will be interpreted as a de facto alternate set of lower standards by those in a position of power and used to endorse the current inadequacies in anesthesia services in many parts of the world. This would maintain the status quo in many lowand middle-income countries. ${ }^{6}$

Conflicts of interest None declared.

Editorial responsibility This submission was handled by Dr. Hilary P. Grocott, Editor-in-Chief, Canadian Journal of Anesthesia.

\section{References}

1. Hendel S, Banguti P, Workneh RS, et al. Encouraging a bare minimum while striving for the gold standard: a response to the updated WHO-WFSA guidelines. Can J Anesth 2018; 65. DOI: https://doi.org/10.1007/s12630-018-1209-9.
2. Gelb AW, Morriss WW, Johnson W, Merry AF, International Standards for a Safe Practice of Anesthesia Workgroup. World Health Organization - World Federation of Societies of Anaesthesiologists (WHO-WFSA) International Standards for a Safe Practice of Anesthesia. Can. J Anesth 2018; 65: 698-708.

3. Gelb AW, Morriss WWS, Johnson W, et al.; International Standards for a Safe Practice of Anesthesia Workgroup. World Health Organization - World Federation of Societies of Anaesthesiologists (WHO-WFSA) International Standards for a Safe Practice of Anesthesia. Anesth Analg 2018; 126: 2047-55.

4. McQueen K, Coonan T, Ottaway A, et al. The bare minimum: the reality of global anesthesia and patient safety. World J Surg 2015; 39: 2153-60.

5. English Oxford Living Dictionaries. Available from URL: en.oxforddictionaries.com/definition/standard (accessed July 2018).

6. Gelb AW, Enright A, Merry AF, Morriss $W$. The bare minimum requires caution. World J Surg 2016; 40: 2821-2. 